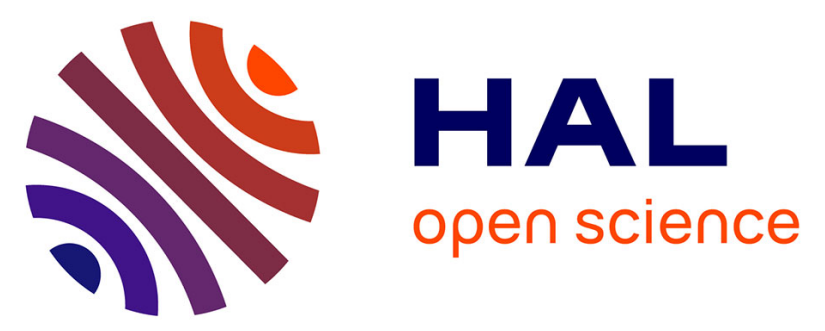

\title{
The middle to upper paleolithic sequence of Buran-Kaya III (Crimea, Ukraine): New stratigraphic, paleoenvironmental, and chronological results
}

Stéphane Péan, Simon Puaud, Laurent Crépin, Sandrine Prat, Anita Quiles, Johannes van Der Plicht, Hélène Valladas, Anthony J Stuart, Dorothée G.

Drucker, Marylène Patou-Mathis, et al.

\section{To cite this version:}

Stéphane Péan, Simon Puaud, Laurent Crépin, Sandrine Prat, Anita Quiles, et al.. The middle to upper paleolithic sequence of Buran-Kaya III (Crimea, Ukraine): New stratigraphic, paleoenvironmental, and chronological results. Radiocarbon, 2013, 55 (2-3), pp.1454-1469. 10.2458/azu_js_rc.55.16379 . hal-00860591

\section{HAL Id: hal-00860591 \\ https://hal.science/hal-00860591}

Submitted on 30 Oct 2020

HAL is a multi-disciplinary open access archive for the deposit and dissemination of scientific research documents, whether they are published or not. The documents may come from teaching and research institutions in France or abroad, or from public or private research centers.
L'archive ouverte pluridisciplinaire HAL, est destinée au dépôt et à la diffusion de documents scientifiques de niveau recherche, publiés ou non, émanant des établissements d'enseignement et de recherche français ou étrangers, des laboratoires publics ou privés. 


\title{
THE MIDDLE TO UPPER PALEOLITHIC SEQUENCE OF BURAN-KAYA III (CRIMEA, UKRAINE): NEW STRATIGRAPHIC, PALEOENVIRONMENTAL, AND CHRONOLOGICAL RESULTS
}

\author{
Stéphane Péan ${ }^{1,2} \bullet$ Simon Puaud $^{1} \cdot$ Laurent Crépin $^{1} \bullet$ Sandrine Prat $^{1,3} \cdot$ Anita Quiles $^{4} \bullet$ \\ Johannes van der Plicht ${ }^{5} \bullet$ Hélène Valladas $^{4} \cdot$ Anthony J Stuart $^{6} \bullet$ Dorothée G Drucker $^{7} \bullet$ \\ Marylène Patou-Mathis ${ }^{1}$ François Lanoë ${ }^{8}$ Aleksandr Yanevich ${ }^{9}$
}

\begin{abstract}
Buran-Kaya III is a rockshelter located in Crimea (Ukraine). It provides an exceptional stratigraphic sequence extending from the Middle Paleolithic to the Neolithic. Nine Paleolithic layers have been attributed to the Streletskaya or eastern Szeletian, Micoquian, Aurignacian, Gravettian, and Swiderian cultural traditions. Human remains from the richest Gravettian layer (6-1) are radiocarbon dated to $31.9 \mathrm{ka} \mathrm{BP}$, and therefore represent, with Peştera cu Oase (Romania), one of the oldest anatomically modern humans in Europe. The aim of this study is to obtain a controlled stratigraphic sequence of Buran-Kaya III with new ${ }^{14} \mathrm{C}$ dates from faunal and human bones, in their paleoenvironmental context. During our new excavations (2009-2011), sediments, bones, and teeth from the stratigraphical layers were sampled for sedimentological, geochemical, and ${ }^{14} \mathrm{C}$ analyses. Fossil bones from the 2001 excavations were also analyzed. Accelerator mass spectrometry (AMS) ${ }^{14} \mathrm{C}$ dating, including cross-dating, was performed at Groningen, Saclay/Gif-sur-Yvette, and Oxford. Biogeochemical analysis was used to test the integrity of the bone collagen. Dates were modeled using a Bayesian approach. The sedimentological, paleoenvironmental, and chronological data are mutually consistent and show that the Paleolithic human occupations at Buran-Kaya III range from the end of MIS 3 to early MIS 1. These results provide a new chronological and paleoenvironmental framework for the human settlements in eastern Europe during the late Middle and the Upper Paleolithic.
\end{abstract}

\section{INTRODUCTION}

The Buran-Kaya III rockshelter (Figure 1) provides an exceptional stratigraphic sequence extending from the Middle Paleolithic to the Neolithic (Janevic 1998; Pettitt 1998; Yanevich 2000; Chabai et al. 2004a; Monigal 2004; Yanevich et al. 2009). This shelter-cave, overhanging the Burulcha River in the Belogorsk region (Figure 2), was discovered in 1990 by A Yanevich and excavated up to 2001 by a team under the direction of A Yanevich and A Marks, with the participation of V Chabai, Y Demidenko, K Monigal, M Otte, and Y Yamada. New fieldwork was undertaken recently from 2009 to 2011 under the direction of A Yanevich and S Péan. The 2001 and 2009-2011 excavations in Buran-Kaya III focused on 9 archaeological layers, which yielded Middle and Upper Paleolithic artifacts (Figure 2): Streletskaya or eastern Szeletian (layer C), Micoquian (layer B), Aurignacian (layers 6-5, 6-4, 6-3), Gravettian (layers 6-2, 6-1, 5-2), and Final Paleolithic (layer 4). A tenth layer (layer 3) is attributed to the Neolithic.

Buran-Kaya III is a key site for understanding the Middle to Upper Paleolithic transition (Chabai et al. 2004b; Anikovich et al. 2007; Demidenko 2008) because it is characterized by a Middle Paleo-

\footnotetext{
${ }^{1}$ Département de Préhistoire/UMR 7194, Muséum National d'Histoire Naturelle, IPH, 1 rue René Panhard, 75013 Paris, France.

${ }^{2}$ Corresponding author. Email: stpean@mnhn.fr.

${ }^{3}$ Laboratoire Dynamique de l'évolution humaine: individus, populations, espèces, UPR 2147, CNRS, 44, rue de l'Amiral Mouchez, 75014 Paris, France.

${ }^{4}$ Laboratoire des Sciences du Climat et de l'Environnement/IPSL, CEA-CNRS-UVSQ, Gif-sur-Yvette, France.

${ }^{5}$ Center for Isotope Research, Groningen University, Groningen/Faculty of Archaeology, Leiden University, Leiden, the Netherlands.

${ }^{6}$ Durham University, South Road, Durham DH1 3LE, United Kingdom.

${ }^{7}$ Department of Geosciences, University of Tübingen, Hölderlinstr. 12, 72074 Tübingen, Germany.

${ }^{8}$ School of Anthropology, University of Arizona, 1009 East South Campus Drive, Tucson, AZ 85721, USA.

${ }^{9}$ Institute of Archaeology, National Academy of Sciences of Ukraine, Heroiv Stalingrada 12, 04210 Kyiv, Ukraine.
}

(C) 2013 by the Arizona Board of Regents on behalf of the University of Arizona

Proceedings of the 21st International Radiocarbon Conference edited by A J T Jull \& C Hatté

RADIOCARBON, Vol 55, Nr 2-3, 2013, p 1454-1469 


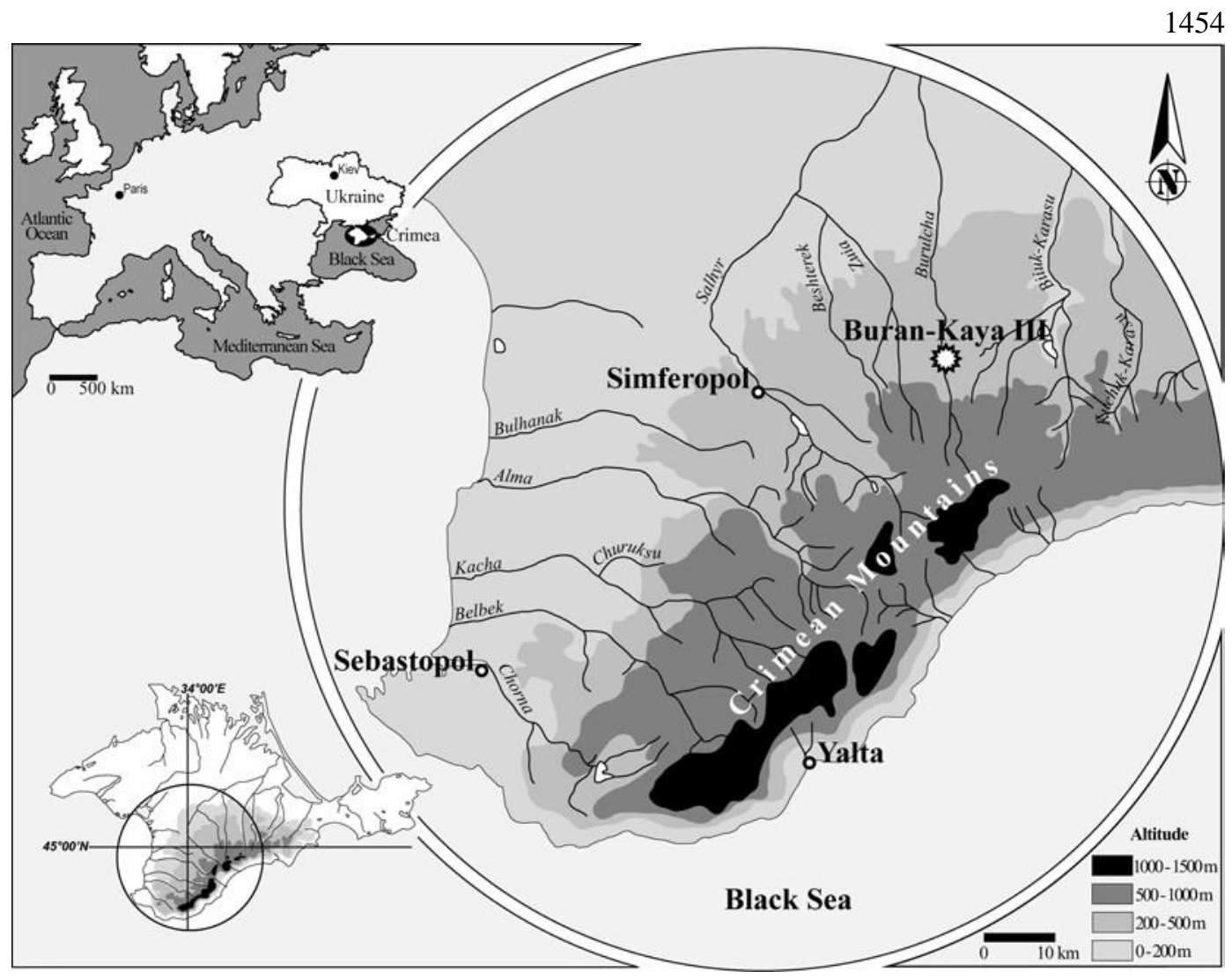

Figure 1 Location of the site of Buran-Kaya III (Crimea, Ukraine) (modified after Prat et al. 2011)

lithic layer (Micoquian, Kiik-Koba type) situated above an Early Upper Paleolithic layer (Streletskaya or eastern Szeletian) and below 3 layers attributed to the Aurignacian complex. Based on radiocarbon dating of this Micoquian layer, the latest Neanderthal settlements in eastern Europe were dated to 28.5 ka BP (34.4-31.7 ka cal BP; Marks and Monigal 2000; Chabai 2001, 2012). Furthermore, direct dating results for a human bone from a Gravettian (sensu lato) layer (6-1) establish a secure presence of anatomically modern humans at 31,900+240/प220 BP (36.9-35.5 ka cal BP) in this region (Prat et al. 2011). They represent the oldest Upper Paleolithic modern humans from eastern Europe in a well-documented archaeological context. Based on taphonomical observations (cut-marks and distribution of skeletal elements), they also show postmortem treatment of the dead.

Previously, $15{ }^{14} \mathrm{C}$ dates were obtained on the Paleolithic layers of Buran-Kaya III (Table 1, Figure 3). These former results were scattered between 36.7 and $10.6 \mathrm{ka} \mathrm{BP}$ and were in part inconsistent with the stratigraphic sequence. Especially, 2 dates from the Micoquian layer at 28.5 and

$28.8 \mathrm{ka}$ BP (respectively, OxA-6673 and -6674) and 2 dates from the Aurignacian layers at 11.9 and $12.0 \mathrm{ka}$ BP (respectively, OxA-4126 and -4127) were younger than the one obtained for an overlying Gravettian layer at $30.7 \mathrm{ka}$ BP (OxA-6882). Furthermore, these 2 samples attributed to the Aurignacian layers show dates of the Late Glacial period. However, the stratigraphic position of these 2 specimens was shown to be uncertain (Marks and Monigal 2000:221). More generally, “... the dates are in a number of cases inverted relative to the stratigraphy" (Jöris et al. 2011:286). Furthermore, regarding the material found during the 1990, 1994, and 1996-1998 fieldwork seasons, 


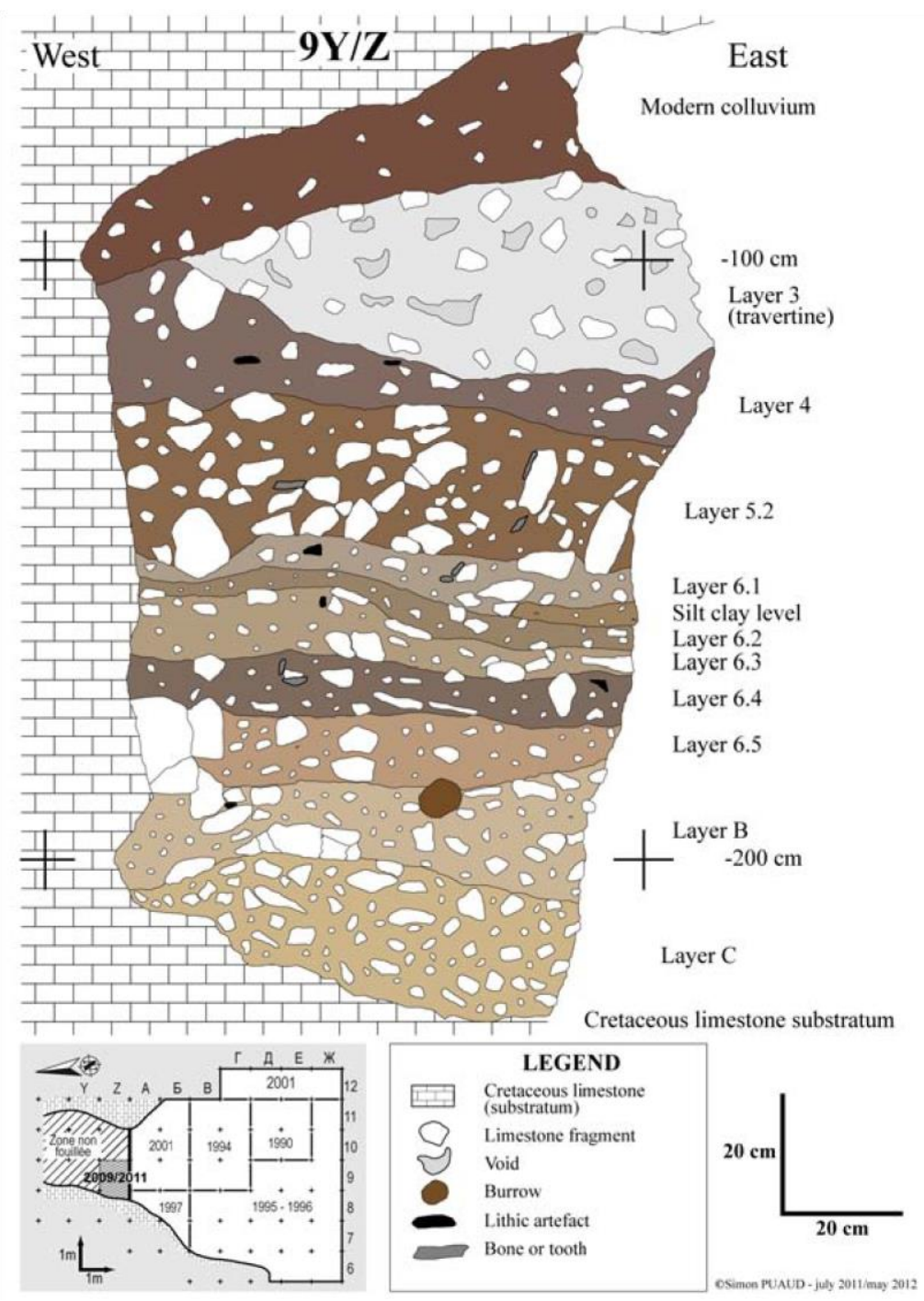

Figure 2 Stratigraphic section of Buran-Kaya III and plan of the excavations

AYanevich considers that postdepositional reworking processes could have affected the stratigraphic information of the Upper Paleolithic layers.

Concerning the human sample published by Higham et al. (2007), its stratigraphic position is questionable. The previous result $(32,790 \pm 280 \mathrm{BP}$, OxA-13302) is considered with care in this article, in view of the associated comments by $\mathrm{C}$ Lalueza-Fox, who pointed out that the result should be questioned, as the human material was recorded from a Mesolithic layer. This human skull fragment was also attributed to layer 6-4, associated with the Aurignacian culture (C Lalueza-Fox and T Higham, personal communications). However, no human bone was discovered in this layer during the last fieldwork seasons in 2001 and 2009-2011, although the entire bone assemblage was carefully checked afterwards in the laboratory in Kiev. Therefore, we prefer to consider this date with caution, as unfortunately the stratigraphic position of the specimen is uncertain.

Table 1 Previously published ${ }^{14} \mathrm{C}$ ages of the Paleolithic layers of Buran-Kaya III, after Hedges et al. 1996 (1), Yanevich et al. 1996 (2), Janevic 1998 (3), Marks 1998 (4), Pettitt 1998 (5), Gerasimenko 2004 (6), Monigal 2004 (7), Otte and Noiret 2004 (8), Higham et al. 2007 (9), and Chabai 2012 (10). 


\begin{tabular}{|c|c|c|c|c|c|c|c|c|c|}
\hline \multirow{2}{*}{$\begin{array}{l}\text { Exca- } \\
\text { vation }\end{array}$} & \multirow{2}{*}{$\begin{array}{l}\text { Sq- } \\
\text { uare }\end{array}$} & \multicolumn{2}{|c|}{ Layer label } & \multirow[b]{2}{*}{ Culture } & \multirow[b]{2}{*}{ Lab code } & \multirow[b]{2}{*}{ Material } & \multirow[b]{2}{*}{${ }^{14} \mathrm{C}$ BP } & \multirow{2}{*}{$\begin{array}{l}\text { Cal age BP } \\
(95.4 \%)\end{array}$} & \multirow{2}{*}{$\begin{array}{l}\text { Refe- } \\
\text { rence }\end{array}$} \\
\hline & & Previous & Curr & & & & & & \\
\hline 1994 & - & horizon 7 & 4 & Swiderian & Ki-6269 & Bone & $10,580 \pm 60$ & $12,651-12,3$ & (3) \\
\hline 1994 & - & horizon 7 & 4 & Swiderian & Ki-6268 & Bone & $10,730 \pm 60$ & $12,762-12$ & $\begin{array}{r}51(6) \\
(10) \\
\end{array}$ \\
\hline 1996 & - & $\begin{array}{l}\text { horizon } \\
17-18\end{array}$ & $6-2$ & Gravettian & OxA-6882 & Bone & $30,740 \pm 460$ & $36,371-34$, & $\begin{array}{r}0(5) \\
(8)\end{array}$ \\
\hline 2001 & 105 & - & - & - & OxA-13302 & $\begin{array}{l}\text { Homo } \\
\text { sapiens } \\
\text { (skull } \\
\text { frag.) }\end{array}$ & $32,790 \pm 280$ & $38,444-36,6$ & (9) \\
\hline 1990 & 11д & $6: 8$ & $6-3$ & & OxA-4126 & Bone & $11,900 \pm 150$ & $14,077-13,4$ & $3(1)$ \\
\hline 1990 & $11 д$ & $6: 9$ & $6-4$ & cian & OxA-4127 & Bone & $11,950 \pm 130$ & $14,092-13,4$ & $\overline{8}(2)$ \\
\hline 1990 & 10 Д & $6: 10$ & $6-5$ & & OxA-4128 & Bone & $28,700 \pm 620$ & $34,602-31,6$ & \\
\hline 1996 & - & horizon 2 & & & OxA-6990 & Bone & $34,400 \pm 1200$ & $41,831-36,80$ & \\
\hline 1990 & $11 \mathrm{E}$ & $7: 1$ & $\mathrm{~B}$ & Micoquian & OxA-4129 & Tooth & $33,210 \pm 900$ & $40,598-36,3$ & $5(1)$ \\
\hline 1990 & 9Д & $7: 2$ & $\mathrm{~B}$ & Kiik Koba & OxA-4130 & Bone & $32,710 \pm 940$ & $39,986-35,2$ & $7(2)$ \\
\hline 1996 & - & $\mathrm{B}$ & $\bar{B}$ & & $\overline{\mathrm{OxA}-6674}$ & Bone & $28,520 \pm 460$ & $34,443-31,7$ & $3(5)$ \\
\hline 1996 & - & $\mathrm{B}$ & $\mathrm{B}$ & & OxA-6673 & Bone & $28,840 \pm 460$ & $34,588-32,0$ & \\
\hline 1996 & - & horizon 2 & & $\begin{array}{l}\text { Streletskaya } \\
\text { or eastern }\end{array}$ & OxA-6869 & $\begin{array}{l}\text { Equus sp. } \\
\text { bone }\end{array}$ & $32,200 \pm 650$ & $38,570-35,2$ & (4) \\
\hline 1996 & - & $\mathrm{C}$ & $\mathrm{C}$ & Szeletian & OxA-6672 & Bone & $32,350 \pm 700$ & $38,749-35,3$ & \\
\hline 1996 & - & $\mathrm{C}$ & $\mathrm{C}$ & & OxA-6868 & Bone tool & $36,700 \pm 1500$ & $4,440-38,865$ & \\
\hline
\end{tabular}

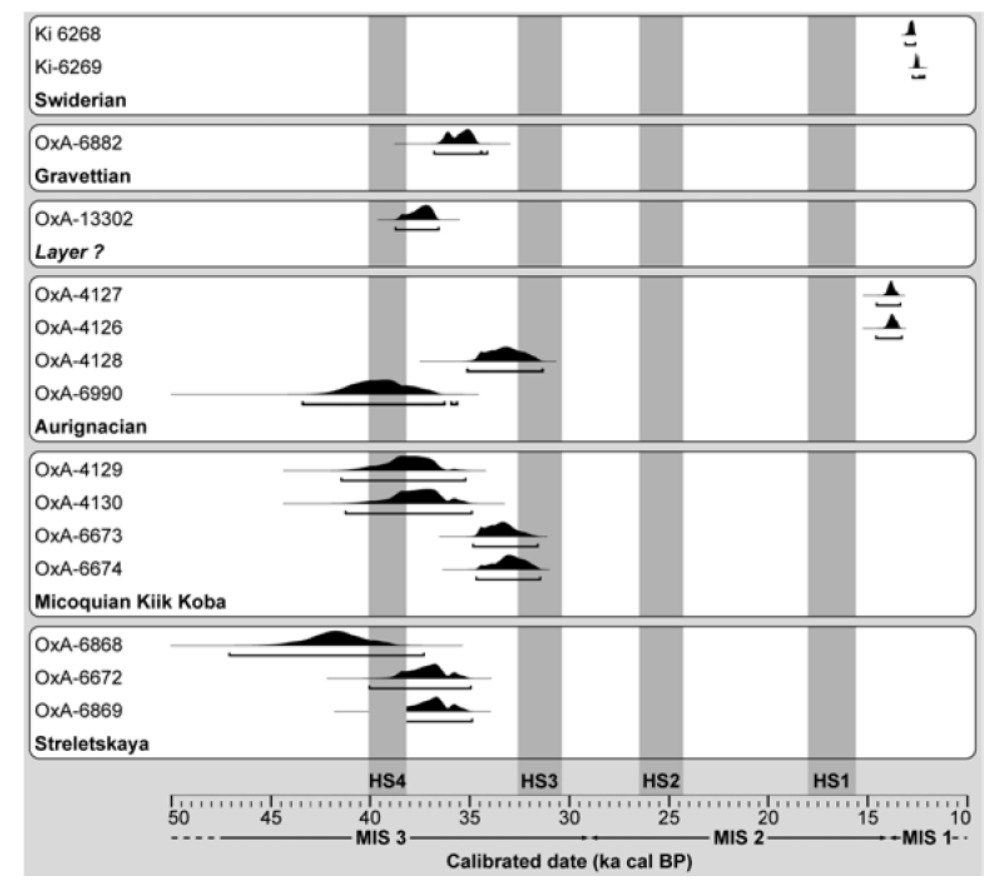

Aurigna-

Figure 3 Previously available ${ }^{14} \mathrm{C}$ ages of the Paleolithic layers from Buran-Kaya III (after Hedges et al. 1996; Yanevich et al. 1996; Janevic 1998; Marks 1998; Pettitt 1998; Gerasimenko 2004; Monigal 2004; Higham et al. 2007).

The heterogeneity in previous dating results and the discussion concerning the stratigraphy urged us to have a stratigraphic control of the sequence and to obtain new ${ }^{14} \mathrm{C}$ dates on bones within the Paleolithic layers of Buran Kaya III. This is reported in this paper. Furthermore, based on new geological, zooarchaeological, and ${ }^{14} \mathrm{C}$ results from large mammal bones, notably human remains, this study 
presents a paleoenvironmental and chronological interpretation of the stratigraphic sequence of Buran-Kaya III.

\section{METHODS}

Stratigraphic and sedimentological analyses were undertaken to better understand the depositional processes of the sedimentary infilling and the paleoenvironmental context of the human settlements in Buran-Kaya III. Sections were drawn and deposits were described macro- and microscopically in order to distinguish the different sedimentary layers and establish a stratigraphic sequence. The texture (sand, silt, clay), composition (quartz, limestone), and porosity of the sediment matrix were recorded. The elements of the coarse fraction (>2 $\mathrm{mm}$ ) were also analyzed in terms of composition, shape, and surface preservation.

New zooarchaeological studies were conducted on the entire faunal assemblage of large mammals from layers C, B, 6-5, 6-4, 6-3 (by M Patou-Mathis), 6-2, 6-1 (by L Crépin), 5-2 (by S Péan), and 4 (by F Lanoë), excavated in 2001 and 2009-2011. Paleoecological information was inferred from the distribution of large mammal associations, following the methodology of Griggo (1995).

Seventeen bones from large mammals, including 2 human remains, were ${ }^{14} \mathrm{C}$ dated by accelerator mass spectrometry (AMS) (Table 2). As far as possible, we sampled bones that could be anatomically and taxonomically determined, showing no postdepositional alteration, and belonging to the taxon preferentially hunted, the saiga antelope (Saiga tatarica). All ${ }^{14} \mathrm{C}$ dates were performed on bones as no charcoal was found in the Paleolithic layers. Six bones from the Gravettian layers excavated in 2001 were sampled in 2008 during our first zooarchaeological studies of the material curated in Kiev. Eleven bones were sampled during our excavations (2009-2011), directly in every excavated archaeological layer of the stratigraphic sequence, from layer B (Micoquian) to layer 4 (Swiderian). The layer C (Streletskaya or eastern Szeletian) did not yield bone materials suitable for sampling. These specimens were not washed and were quickly packed to limit more handling.

Table 2 New samples selected for ${ }^{14} \mathrm{C}$ AMS dating from Buran-Kaya III.

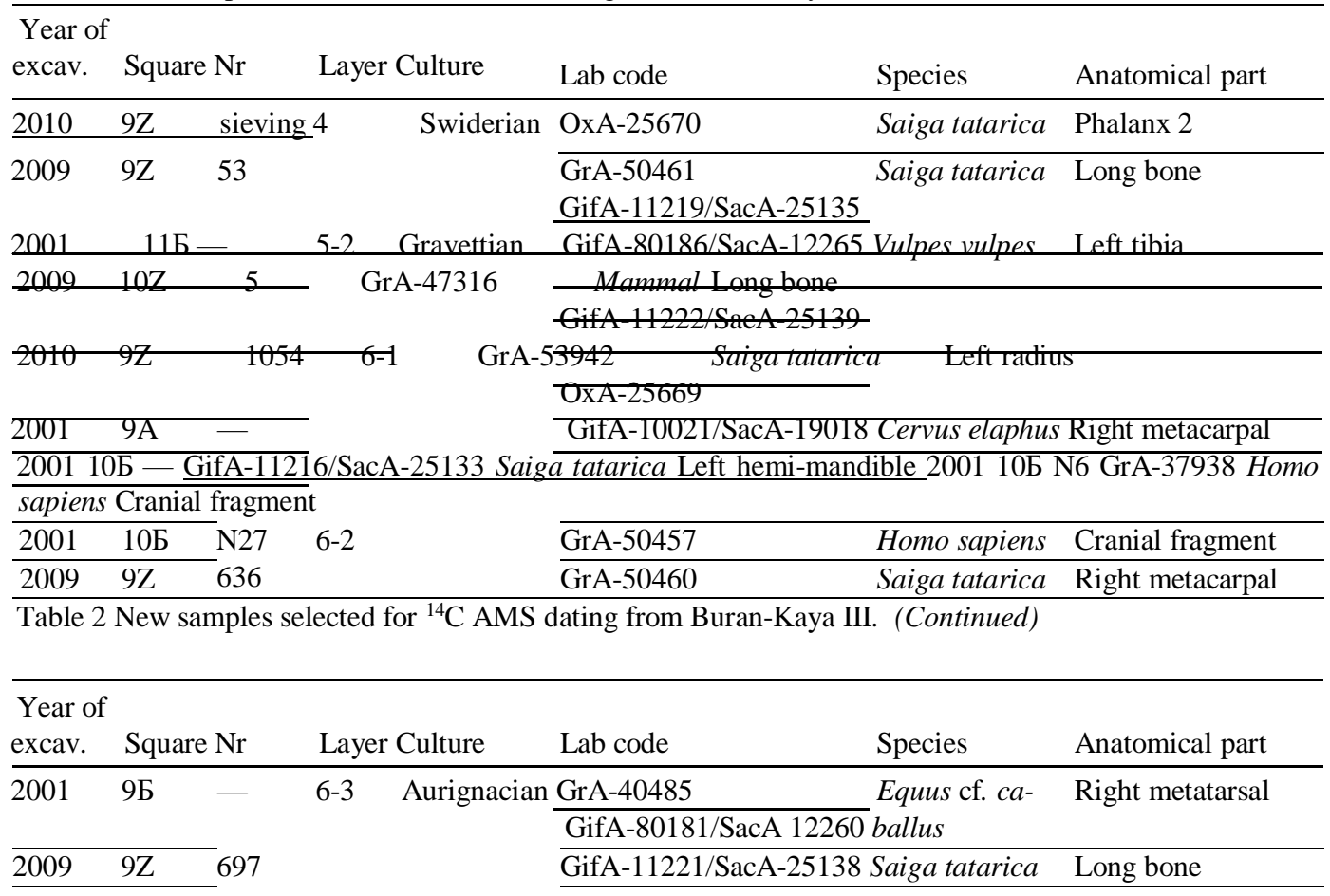




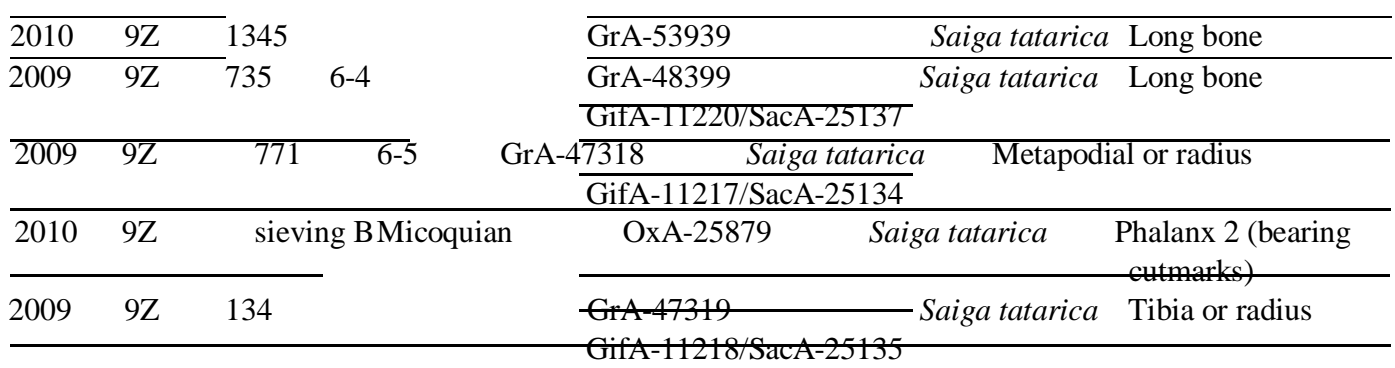

Three different laboratories performed ${ }^{14} \mathrm{C}$ AMS dating. This included cross-dating, applying 3 methods of collagen extraction. At the Center for Isotope Research in Groningen, Netherlands (GrA), the collagen extraction was performed following a protocol adapted from Longin (1971). At the Laboratoire des Sciences du Climat et de l'Environnement (LSCE) using the Artemis facility of the Laboratoire de Mesure du C-14 (LMC-14, Commissariat à l'Energie Atomique, Saclay/GifsurYvette, France) (GifA/SacA), bones were prepared following the method proposed by Nelson (1999), based on chemical reaction between ninhydrin and the amino-acids of collagen (TisnératLaborde et al. 2003). At the Oxford Radiocarbon Accelerator Unit (ORAU), Oxford, United Kingdom (OxA), bone collagen was extracted employing sequential decalcification, base wash, gelatinization, filtration and ultrafiltration steps to remove low molecular weight contaminants (Higham et al. 2006).

Six bones were cross-dated by Groningen and LSCE laboratories: 4 saiga antelope (Saiga tatarica) long bones from layers B, 6-5, 6-4 and 4; 1 mammal long bone from layer 5-2; and 1 horse (Equus cf. caballus) metatarsal initially attributed to layer 6-2 (Prat et al. 2011). This horse specimen was sampled in 2008 before our most recent fieldwork and stratigraphic description, which revealed that the thickness of layer 6-2, where it was found, is smaller than the bone length. Its stratigraphic origin remains questionable indeed and one can suspect that it actually could come from an underlying layer. In addition, 1 saiga antelope (Saiga tatarica) radius from layer 6-1 was cross-dated by Groningen and ORAU.

The chemical composition of the collagen is used to assess the reliability of the isotopic measurements. We determined the preservation of the bone collagen using the $\mathrm{C} / \mathrm{N}$ atomic ratios, which are classically given to testify the quality of the collagen submitted for ${ }^{14} \mathrm{C}$ dating (van Klinken 1999). C/N ratios were obtained from the dated collagen or from collagen extracted at the Center for Archaeological Science, University of Tübingen, following a protocol adapted from Longin (1971). The dates were calibrated using the IntCal09 calibration curves (Reimer et al. 2009) using OxCal v 4.2.2 and modeled using a Bayesian approach (Bronk Ramsey 2009a). In addition, the OxCal outlier detection method (Bronk Ramsey 2009b) was performed to identify outlier samples.

\section{RESULTS AND DISCUSSION Stratigraphy and Paleoenvironment}

The new sedimentological and stratigraphic studies indicate that there are no reworking processes on the square excavated during the 2001 and 2009-2011 seasons. The layers are in situ and well defined and constrained. The sedimentary infilling of Buran-Kaya III is composed of a sequence of diamicton layers divided into 2 sedimentary units. The coarse and fine carbonate fractions result from the destruction of the limestone wall. The fragments are morphologically identified as frost shattered scales (Ferrier 2002); their edges can be more blunted in the lower part. The grain size and sorting of the matrix, which comes from the plateau, are typical of an eolian deposit (Antoine and Lautridou 2008).

The lower unit (C to 6-2) is characterized by limestone fragments with a scarce unsorted sandy silt matrix. The development of frost shattering associated with sandy loam sediments indicates 
contrasting climatic conditions: cold and wet winters, followed by less severe but still moist periods with runoff into the shelter.

In the upper unit (silt-clay level, 6-1 to 5-2), the coarse fraction is less abundant and the matrix becomes more silty and better sorted. The seasonal contrasts are less pronounced and are dominated by an eolian deposit; the climatic conditions become significantly drier than below. Layer 4 contains more organic matter and coarse fraction. It presents characteristics of contrasting conditions (frost shattering/biological and pedological activities).

The differences in large mammal associations along the stratigraphic sequence, based on new and previously published data (Laroulandie and d'Errico 2004; Patou-Mathis 2004; Crépin and Péan in Yanevich et al. 2009; Crépin in Prat et al. 2011; Lanoë 2011), allows us to reconstruct different paleoenvironmental conditions (Figure 4). In all layers, the large mammal assemblages show a predominance of steppe species such as saiga antelopes, horses, red or polar foxes, and hares. The Streletskaya or Eastern Szeletian layer C was deposited in a mixed steppe (saiga antelope and horse) and forest (large and small cervids) paleoenvironment, under a cold and wet but not harsh climate. The Micoquian layer B shows an open and semi-arid steppe (with woolly mammoth and woolly rhinoceros) with a few forested areas (with red deer and mustelids), probably located alongside the river, under harsh climatic conditions, especially during winter. In the lower Aurignacian layer 6-5, the environment was still a cold and dry steppe (no cervid). From the Aurignacian layer 6-4 to the Gravettian layer 6-2, the climate was relatively cold, but not harsh, and relatively dry (not arid in 64 , with the presence of red deer) in a general steppe environment (presence of reindeer). In the upper Gravettian layers 6-1 and 5-2, the faunal assemblage shows the most diversified spectrum of the sequence. The climate became drier and colder (presence of reindeer, woolly rhinoceros, and marmot), especially at the top of these layers, with less-contrasting seasons and, at the same time showing evidence of more forested areas around the site (presence of brown bear, wild cat, red deer, wild boar, and mustelids). During the Final Paleolithic (layer 4), the climatic conditions became wet; forested animals (red deer, wild boar, mustelids) were dominant at that time.

The palynological study (Gerasimenko 2004, 2007) indicates a general steppe environment with alternating dry (xeric conditions in 5-2) and wet periods (6-1 and B). The study of micromammals shows similar evolutionary trends to the other paleoenvironmental data (Markova 2004), with a progressive increase in aridity from the layer $\mathrm{C}$ to the driest layer 5-2.

Based on the consistent results from pollen, microfauna, and large mammal studies, the paleoecological context of Buran-Kaya III can, on the whole, be described as an open and steppelike periglacial environment characterized by a reduced tree cover (along the river) under a cold and dry climate. The faunal diversity in Buran-Kaya III could result from the proximity of different environments (steppe, riparian forest, and plateau) around the site. 


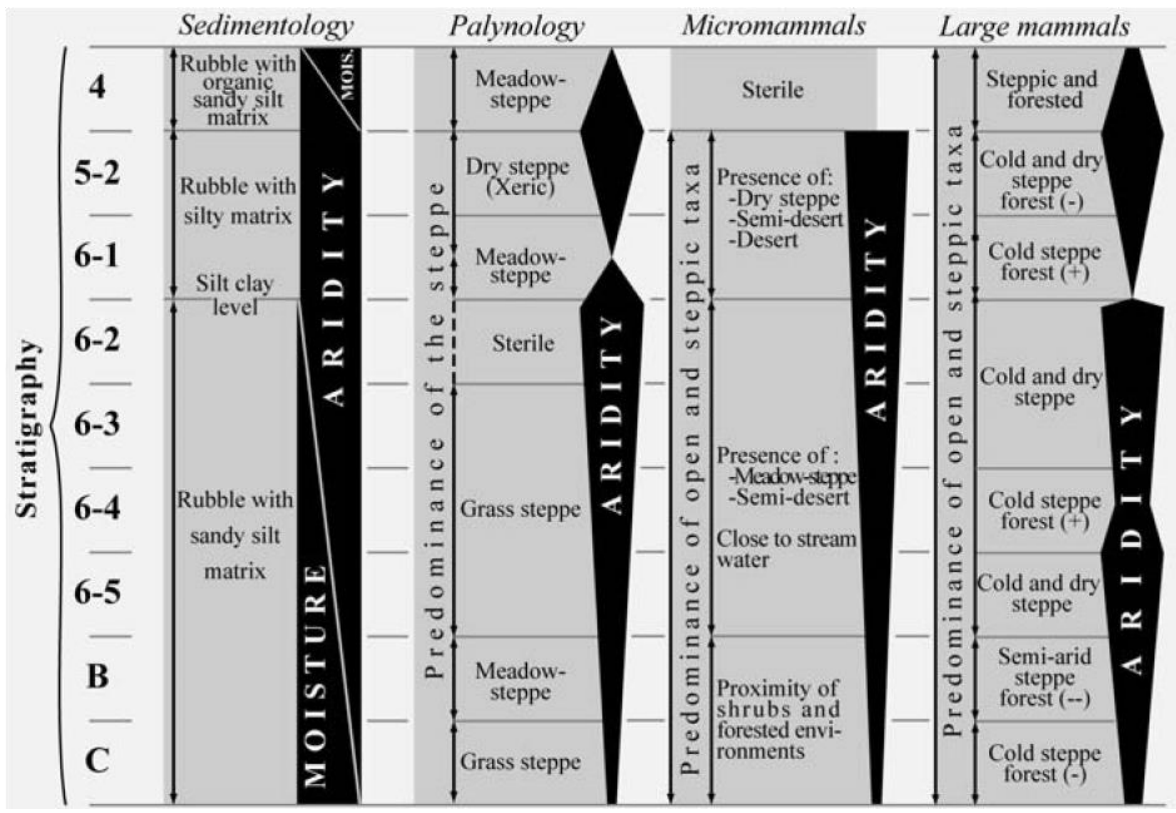

Figure 4 Paleoenvironmental interpretation of sediments, pollen, and faunal remains from Buran-Kaya III

\section{Radiocarbon Dates}

Some $24{ }^{14} \mathrm{C}$ dates were obtained on the 17 large mammal bones, 2 of which are human remains, associated with all layers, from layer B (Micoquian) to layer 4 (Swiderian) (Table 3, Figure 5). These results include 7 cross-dated samples. The number of ${ }^{14} \mathrm{C}$ dates was limited by the absence of charcoal and scarcity of identified faunal material appropriate for dating.

Table $3 \mathrm{New}{ }^{14} \mathrm{C}$ dates of the Buran-Kaya III sequence. Datings performed on the same sample are framed together. The dates were calibrated using the software OxCal v 4.2.2 (Bronk Ramsey 2009a,b) based on the IntCal09 calibration data set (Reimer et al. 2009). The largest values of error (+ or $\square$ ) are used for calibration. nd: no data available. *: lowest collagen yield value (1\% weight) of the sample set.

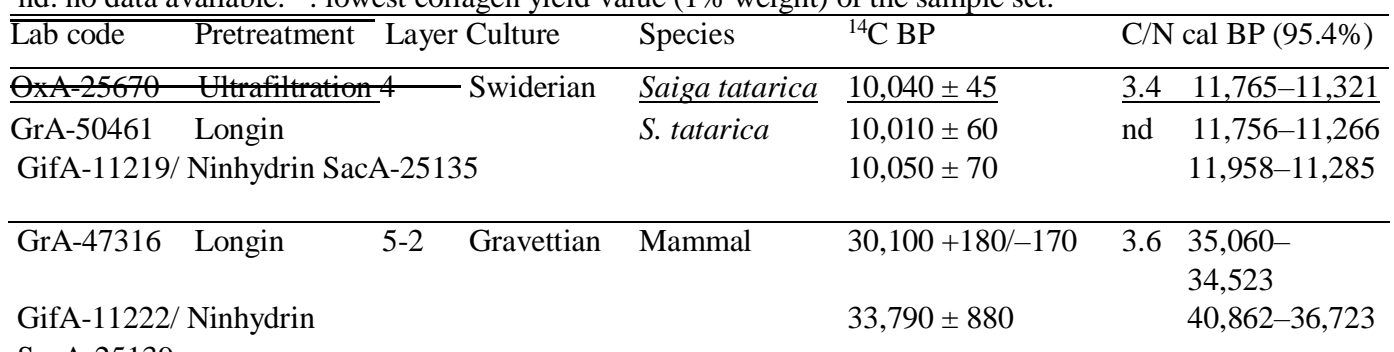

SacA-25139

GifA-80186/ Ninhydrin

Vutpes vutpes $24,070 \pm 260 \quad 3.5 \quad 29,484-28,347$

SacA-12265

GrA-53942 Longin 6-1 S. tatarica 29,640 +170/-160 3.3 34,481-33,168 OxA-25669 Ultrafiltration 32,200 \pm $45038,430-35,505$

GifA-10021/ Ninhydrin

\begin{tabular}{lll}
\hline Cervus elaphus $31,320 \pm 820$ & 3.3 & $38,357-34,582$
\end{tabular}

SacA-19018

GifA-11216/ Ninhydrin

SacA-25133

S. tatarica $\quad 31,530 \pm 670 \quad 3.4 \quad 37,735-34,749$


GrA-37938 Longin Homo sapiens 31,900 +240/-220 3.3 36,930-35,503 GrA-50460 Longin 6-2 S. tatarica 29,440+190/-180 3.3 34,643-33,486 GrA-50457 Longin H. sapiens 32,450+250/-230 3.1 37,831-36,450

Table $3 \mathrm{New}{ }^{14} \mathrm{C}$ dates of the Buran-Kaya III sequence. Datings performed on the same sample are framed together. The dates were calibrated using the software OxCal v 4.2.2 (Bronk Ramsey 2009a,b) based on the IntCal09 calibration data set (Reimer et al. 2009). The largest values of error (+ or Q) are used for calibration. nd: no data available. *: lowest collagen yield value (1\% weight) of the sample set. (Continued)

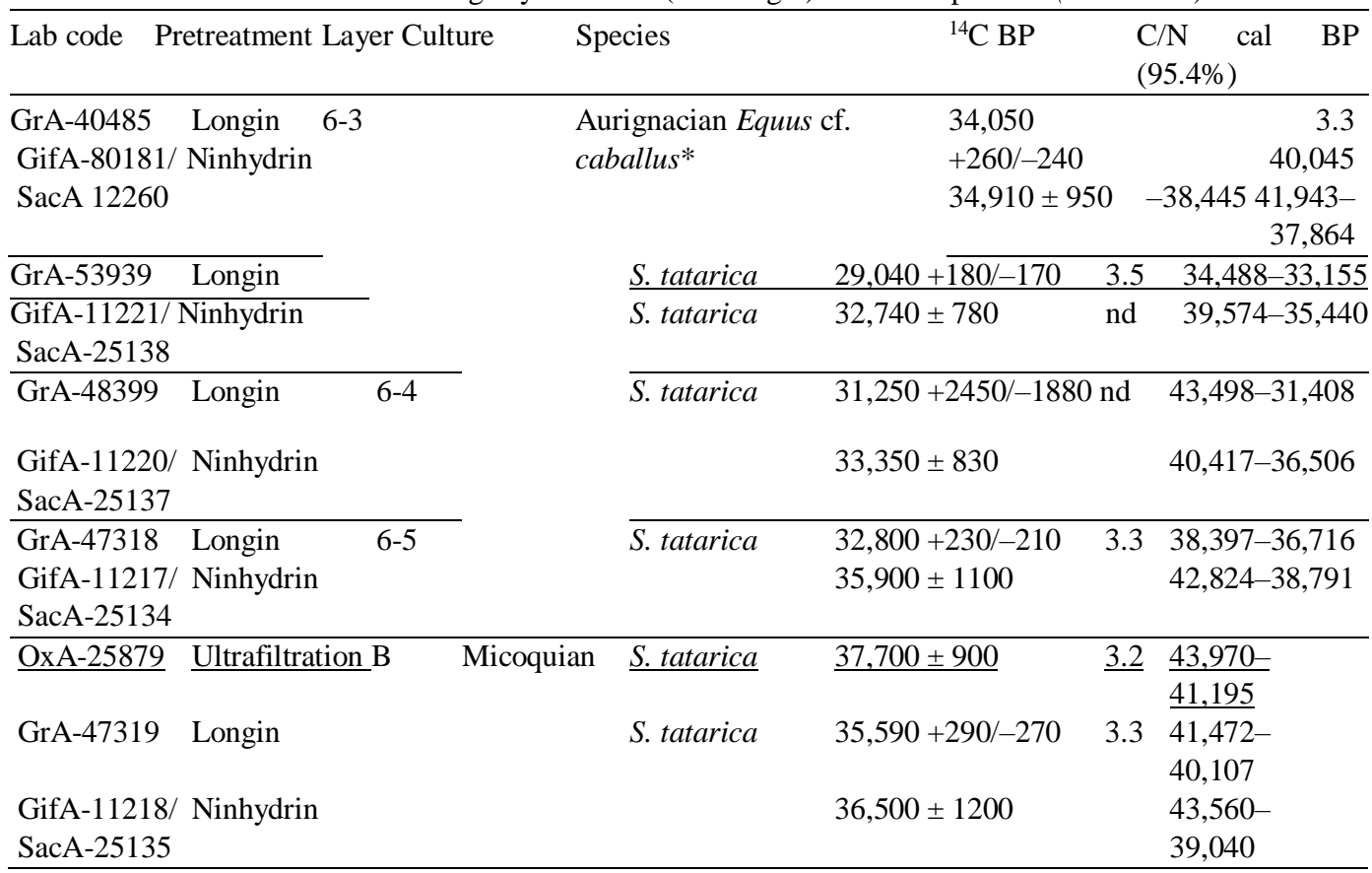

The $\mathrm{C} / \mathrm{N}$ atomic ratios of the 14 tested bone samples for ${ }^{14} \mathrm{C}$ and stable isotope $\left(\mathrm{C}^{13} \mathrm{C}\right.$ and $\left.\mathrm{Q}^{15} \mathrm{~N}\right)$ analyses are between 3.0 and 3.6, i.e. within the acceptable range of 2.9-3.6 expected for wellpreserved collagen (DeNiro 1985; Ambrose 1990). The collagen samples dated and tested contain $31.7-45.7 \%$ carbon and $10.3-16.0 \%$ nitrogen. These percentages correspond to chemically nonaltered collagens. Furthermore, the obtained collagen yield values range between $1 \%$ and $10 \%$ weight, i.e. above the threshold defined by van Klinken (1999). It should be noted that the horse bone sample (GrA-40485), which provided the lowest collagen yield, could be taken with caution. On the whole, the quality parameter values support the accuracy of the ${ }^{14} \mathrm{C}$ results.

${ }^{14} \mathrm{C}$ results obtained from the 7 cross-dated samples and their calibrated deduced dates are shown in Table 4. Bayesian analysis enables the combining of ${ }^{14} \mathrm{C}$ results performed on the same sample, providing an agreement factor (Ai). For 6 samples, the agreement factor was good enough (Ai > 81) to validate the combination; the deduced combined densities were then used in the modeling.

The results that failed this criterion are those obtained from the Gravettian Saiga tatarica specimen (layer 6-1), dated to 29,640 $\pm 170 \mathrm{BP}$ (GrA-53942) and 32,200 $\pm 450 \mathrm{BP}$ (OxA-25669) (Ai = 27). Additionally, due to a very large uncertainty $(+2450 / 01880 \mathrm{yr})$ of the date GrA-48399, we decided to reject the combination of the layer 6-4 and to exclude this date from the interpretation of the results. Therefore, only the other result from the same sample (GifA-11220/SacA-25137) was considered for the following modeled analyses.

Table 4 Intercomparisons of new calibrated ${ }^{14} \mathrm{C}$ dates for the Buran-Kaya III sequence, using the IntCal09 calibration curves (Reimer et al. 2009; OxCal online, Bronk Ramsey 2009a). 


\begin{tabular}{|c|c|c|c|c|c|c|c|}
\hline Lab code & $\begin{array}{l}\text { Layer } \\
\quad \text { Culture }\end{array}$ & Species & ${ }^{14} \mathrm{C} \mathrm{BP}$ & $\begin{array}{l}\text { Combination } \\
\text { name }\end{array}$ & $\begin{array}{l}\text { R_Combined } \\
(\mathrm{BP})\end{array}$ & $\begin{array}{l}\text { Calibrated } \\
\text { range }(95.4 \%)\end{array}$ & $\mathrm{Ai}$ \\
\hline GrA-50461 & \multirow{2}{*}{$\begin{array}{l}\text { Swide- } \\
\text { rian }\end{array}$} & \multirow{2}{*}{$\begin{array}{l}\text { Saiga ta- } \\
\text { tarica }\end{array}$} & $10,010 \pm 60$ & \multirow[t]{2}{*}{ Combine 4} & \multirow[t]{2}{*}{$10,027 \pm 46$} & \multirow[t]{2}{*}{$11,757-11,313$} & \multirow[t]{2}{*}{99} \\
\hline $\begin{array}{l}\text { GifA-11219/ } \\
\text { SacA-25135 }\end{array}$ & & & $10,050 \pm 70$ & & & & \\
\hline$\frac{\text { GrA-47316 }}{\text { GifA-11222/ }}$ & \multirow[t]{2}{*}{$\begin{array}{c}\text { 5-2 Grave- } \\
\text { ttian }\end{array}$} & Mammal & $\begin{array}{l}30,100 \pm 180 \\
33,790 \pm 880\end{array}$ & Combine 5-2 & $30,386 \pm 178$ & $35,095-34,515$ & 81 \\
\hline $\begin{array}{l}\text { SacA-25139 } \\
\text { GrA-53942 }\end{array}$ & & S. tatar- & $29,640 \pm 170$ & Combine 6-1 & $30,120 \pm 161$ & $34,781-33,730$ & 27 \\
\hline$\overline{\mathrm{OxA}}-25669$ & & $i c a$ & $32,200 \pm 450$ & & & & \\
\hline
\end{tabular}

Table 4 Intercomparisons of new calibrated ${ }^{14} \mathrm{C}$ dates for the Buran-Kaya III sequence, using the IntCal09 calibration curves (Reimer et al. 2009; OxCal online, Bronk Ramsey 2009a). (Continued)

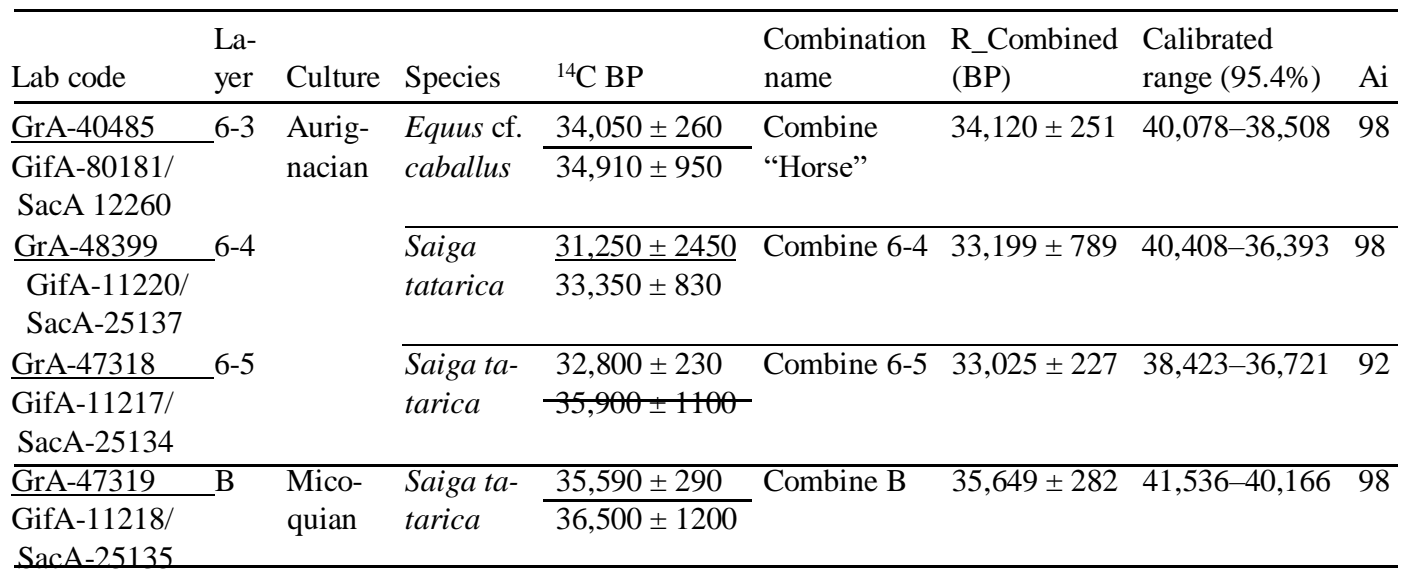

A red fox tibia of layer 5-2 dates to $24,070 \pm 260 \mathrm{BP}$ (GifA-80186/SacA-12265). This is younger than the 2 other dates from this layer $(33,790 \pm 880$ BP [GifA-11222/SacA-25139] and 30,100 $+180 /$ 170 BP [GrA-47316]). If we consider the possibility that this fox element could be intrusive, its original stratigraphical position is doubtful. Therefore, this date is not considered in the following modeled analyses.

The remaining ${ }^{14} \mathrm{C}$ dates were modeled using a Bayesian approach. Samples archaeologically attributed to a same cultural unit were placed in a phase, and the 4 phases (Micoquian, Aurignacian complex, Gravettian complex, Swiderian) were then sequenced according to the stratigraphy (Figure 5). The Bayesian analysis was conducted on a total of 15 samples (including 5 combinations) corresponding to 20 dates.

The Buran-Kaya model was run 3 times to obtain a final model (Figure 5) with a high agreement index for the whole modeling $\left(\mathrm{A}_{\text {model }}=113\right)$. The first run of the model showed that GrA-53939 was an outlier, which was subsequently rejected. The second run (on a total of 14 samples and 19 dates) provided a model with a low validity $\left(\mathrm{A}_{\text {model }}<60\right)$, which meant that the stratigraphic sequence did not agree with the ${ }^{14} \mathrm{C}$ results. As explained above, the stratigraphic origin of the large horse bone (GrA-40485) from layer 6-2 remains questionable. If we rerun the program after attributing this specimen to layer 6-3 rather than to 6-2, the model is validated with a final agreement index equal to 113 . In that case, ${ }^{14} \mathrm{C}$ results and stratigraphy concur perfectly.

The cultural assemblages show the following calibrated ${ }^{14} \mathrm{C}$ ages with a $2 \square$ range:

- The Micoquian (layer B) settlements are modeled from 44.0 to $40.2 \mathrm{ka}$ cal BP; 
- The occupations attributed to the Aurignacian complex (layers 6-5, 6-4, and 6-3) and theGravettian complex (layers 6-2, 6-1, and 5-2) are modeled within a close timespan between 40.4 and $33.5 \mathrm{ka}$ cal BP.

- After a chronological gap of about 20,000 yr, the Swiderian layer is modeled from 11.8 to $11.3 \mathrm{ka}$ cal BP.

The ${ }^{14} \mathrm{C}$ date of a human cranial fragment (from layer 6-2) is 32,450 +250/प230 BP (GrA-50457), calibrated to 37.8-36.5 ka cal BP. This makes the second direct dating of an early modern human remain from Buran-Kaya III; the first was from layer 6-1 (Prat et al. 2011). Both specimens represent, together with Peştera cu Oase, Romania (Oase 1: 34,290 +970/प870 [GrA-22810]; Trinkaus et al. 2003), the earliest occurrence of anatomically modern humans in eastern Europe; furthermore, the modern human remains from Buran-Kaya III are the most eastern ones (east of $34^{\circ} \mathrm{E}$ longitude). 

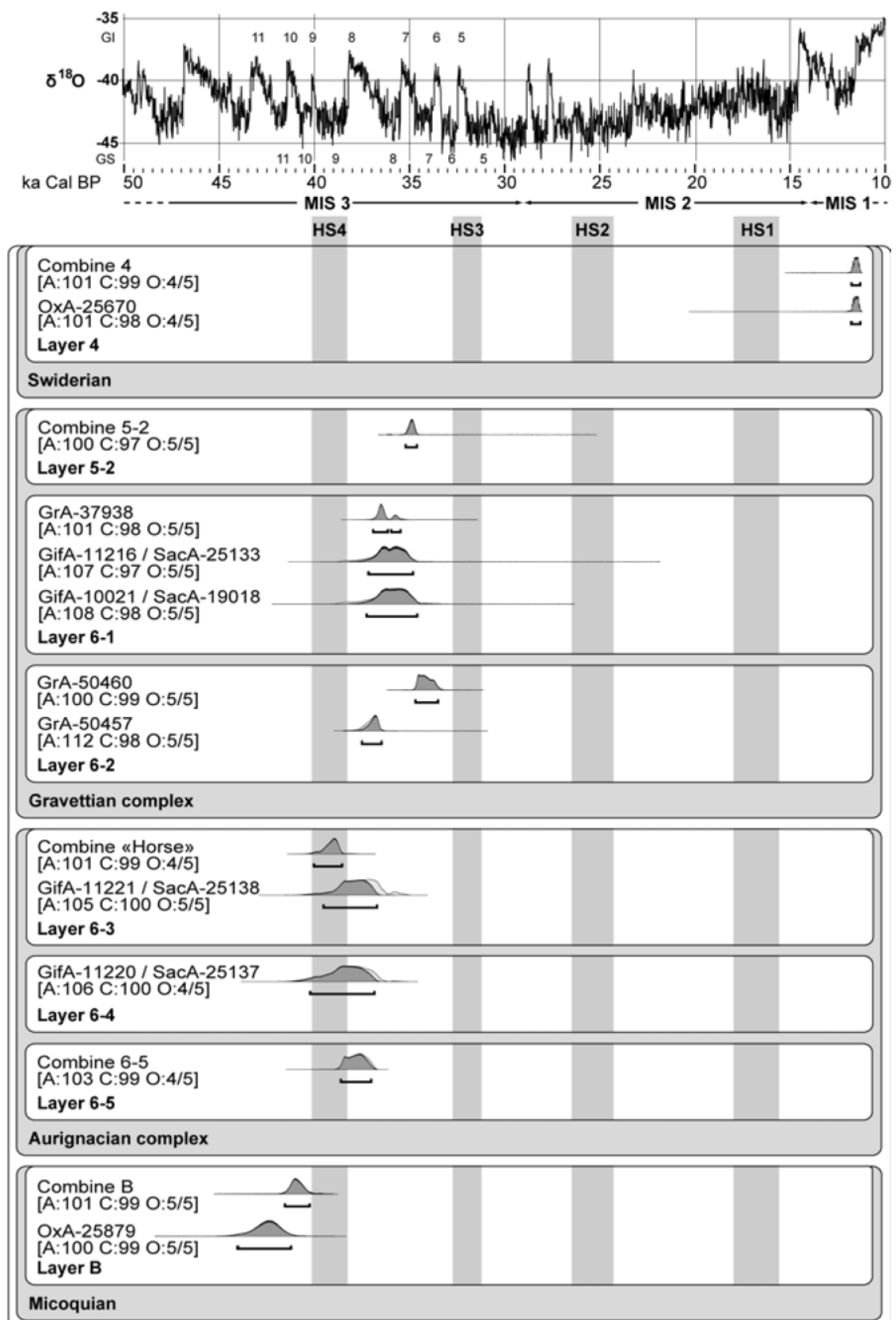

Sequence Buran Kaya III [Amodel:113]

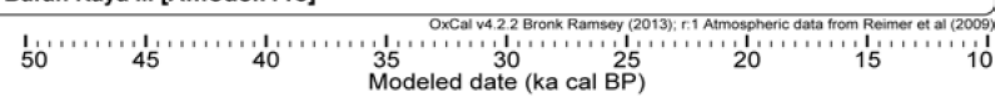

Figure 5 Bayesian modeling of the new ${ }^{14} \mathrm{C}$ dates for the Buran-Kaya III sequence, produced using OxCal v 4.2.2 (Bronk Ramsey 2009a,b) based on the IntCal09 calibration data set (Reimer et al. 2009), in the global climatic context ( $\delta^{18}$ O GRIP curve, Dansgaard et al. 1989, 1993; Dahl-Jensen et al. 1993; GRIP Members 1993; Grootes et al. 1993; Johnsen et al. 1995, 1997; Stuiver et al. 1995; Hammer et al. 1997; Lisiecki and Raymo 2005; Sánchez Goñi and Harrison 2010). 


\section{Discussion}

In contrast to the previously published ${ }^{14} \mathrm{C}$ dates (Table 1), our new set of $24{ }^{14} \mathrm{C}$ dates from 3 different laboratories shows a high consistency with the stratigraphy. Six cross-datings, out of the 7 performed, show a good reproducibility of the ${ }^{14} \mathrm{C}$ results.

Our results support an early chronological framework for the Middle to Upper Paleolithic period in southeastern Europe. They show an old presence of Early Upper Paleolithic (Streletskaya or eastern Szeletian) populations in Crimea, older than $40.0 \mathrm{ka}$ cal BP. This confirms a previous dating of 44.4-38.9 ka cal BP (36.7 $\pm 1500 \mathrm{ka}$ BP, OxA-6868) of the Streletskaya or eastern Szeletian layer (C) in Buran-Kaya III (Marks 1998). This date was obtained on a bone industry artifact ("bone rod"; Marks 1998). It provided early evidence of this type of transitional industry.

The results indicate a timespan of 44.0-40.2 ka cal BP for the presence of Late Middle Paleolithic populations in Crimea, which is much older than was previously proposed $(28.5 \pm 460 \mathrm{ka} \mathrm{BP}$ [OxA6674] and 28.8 $\pm 460 \mathrm{ka} \mathrm{BP} \mathrm{[OxA-6673],} \mathrm{i.e.} \mathrm{34.6-31.7} \mathrm{ka} \mathrm{cal} \mathrm{BP,} \mathrm{Marks} \mathrm{and} \mathrm{Monigal} \mathrm{2000;}$ Chabai 2001). Thus, our new ${ }^{14} \mathrm{C}$ dates for the Micoquian layers of Buran-Kaya III cast doubt on the existence of Neanderthal refugial survival in Crimea after $40 \mathrm{ka} \mathrm{cal} \mathrm{BP.} \mathrm{The} \mathrm{same} \mathrm{conclusion}$ has recently been reached at other Neanderthal refugial survivals in southern Spain (Zaffaraya; Wood et al. 2013), northern Caucasus (Mezmaiskaya Cave; Pinhasi et al. 2011), and southern Caucasus (Ortvale Kdle; Adler et al. 2008).

Our results also show that 2 Upper Paleolithic cultural traditions, related to the Aurignacian and Gravettian complexes, were successively present in Crimea in a short timespan between 40.4 and $33.5 \mathrm{ka}$ cal BP. All the Upper Paleolithic settlements (layers 6-5 to 5-2) occurred during a short period between the 2 Heinrich stadials HS 4 and HS 3 (Sánchez Goñi and Harrison 2010). At last, after a gap of about $20,000 \mathrm{yr}$, the site was totally discarded or no depositional process occurred. The Final Paleolithic populations (Swiderian) settled in Crimea between 11.8 and $11.3 \mathrm{ka} \mathrm{cal} \mathrm{BP}$, i.e. during MIS 1.

If we compare all the stratigraphic, ${ }^{14} \mathrm{C}$, and paleoecological data, the paleoenvironmental changes along the sequence of Buran-Kaya III fit with the global climatic changes in Europe (Arslanov et al. 2007; Sánchez Goñi et al. 2008; Dolukhanov and Arslanov 2009; Naughton et al. 2009; Fletcher et al. 2010), in particular during the Middle/Upper Paleolithic transition (Jöris and Street 2008; Jöris et al. 2011). The bottom part (layers C and B) is characterized by species from open and steppe-like environment, with a significant number of taxa that are characteristic of forest and shrub areas; this is coherent with the generally quite temperate climatic conditions that developed during Greenland Interstadial (GI) events. The late Micoquian occupations, attributed to Neanderthals, mainly occurred during GI 11-9, i.e. just before or at the beginning of the cold episode HS 4. During the Aurignacian, the climate was relatively cold and dry (but not arid) in a steppe-like environment. The dates indicate that all the Aurignacian settlements probably occurred at late HS 4, which is coherent with the information obtained from the faunal remains. The silt-clay level deposit probably results from a short cold and very dry event, during HS 4 or more likely the Greenland Stadial GS 9. During the deposition of the Gravettian layers, the environment became dry with less-contrasting seasons; the faunal spectrum was more diversified. These settlements occurred under interstadial climatic conditions (such as GI 8 or 7), which became colder and drier (during GS 7 or 6). The Final Paleolithic layer indicates a temperate and wet period with the predominance of forest animals (MIS 1).

\section{CONCLUSION}

This study allows us to propose a new chronostratigraphical and paleoenvironmental context for Buran-Kaya III. Our results provide an early chronological framework for the Middle to Upper Paleolithic period and a new chronological context for the demise of Late Neanderthal and arrival 
of early modern humans in Europe. Our results reinforce an early presence of Early Upper Paleolithic industry (Streletskaya or eastern Szeletian) in eastern Europe. Moreover, Buran-Kaya III is the only site that presents a peculiar stratigraphic position of an Early Upper Paleolithic layer (associated with bone industry) underlying a Middle Paleolithic layer. The new ${ }^{14} \mathrm{C}$ dates from the Micoquian layers of Buran-Kaya III cast doubt on the existence of Neanderthal refugial survival in Crimea after $40 \mathrm{ka}$ cal BP. Furthermore, our findings fill an important gap in the study of modern human settlements in eastern Europe. The human fossils from layers 6-1 (Prat et al. 2011) and 6-2 directly dated to $36 \mathrm{ka}$ cal BP represent the oldest direct evidence of the presence of modern humans in far southeastern Europe.

In Buran-Kaya III, the Early Upper Paleolithic (Streletskaya or eastern Szeletian) and Late Middle Paleolithic settlements occurred before HS 4, or during early HS 4 for the Middle Paleolithic ones, in a mixed steppe and forested environment, under a cold and semi-arid climate. The first settlements attributed to the Aurignacian complex probably occurred during late HS 4, in a drier environment, without forested areas. During the Middle to Upper Paleolithic transition, the human settlements in Buran-Kaya III seem to have been quite continuous with no significant gap. The settlements attributed to the Aurignacian and Gravettian complexes occurred between HS 4 and HS 3, during a succession of short warm and cold episodes.

Regardless of the paleoclimatic context, the Paleolithic faunal spectrum in Buran-Kaya III remained typical of an open and steppe-like periglacial environment, with more or less forested areas. The specific location of the rockshelter on the ridges of the Crimean Mountains, in a transition zone between steppes and mountains, where different biotopes existed (steppe, riparian forest, and plateau), could have been an important reason for the continuity of human settlements.

\section{ACKNOWLEDGMENTS}

We thank the National Academy of Sciences of Ukraine for permission to excavate at BuranKaya III and all the team members of the 2001 and 2009-2011 excavation seasons. We are grateful to A Lister (Oxford ${ }^{14} \mathrm{C}$ dates as part of a NERC-funded Megafaunal extinction project with A J Stuart), E Kaltnecker (LSCE/UVSQ, bone sample preparation), C Moreau (LMC-14, ${ }^{14} \mathrm{C}$ dating on Artemis), and T Higham (chemical information on a dated specimen in ORAU). The analyses were supported by the ANR "Mammouths" Research Program No. ANR-05-JCJC-0240-01 of the French National Research Agency (Agence Nationale de la Recherche), the ATM Program "Relations Sociétés-Nature dans le long terme" of the Muséum National d'Histoire Naturelle (MNHN, Paris), and the UPR 2147 of the Centre National de la Recherche Scientifique (CNRS). The MNHN and CNRS funded the 2009-2011 field seasons. Current field and lab research about Buran-Kaya archaeological sites are supported by the MNHN, the CNRS, the Fondation Fyssen (Paris), and the French Ministère des Affaires étrangères et européennes.

\section{REFERENCES}

Adler DS, Bar-Yosef O, Belfer-Cohen A, Tushabramishvili N, Boaretto E, Mercier N, Valladas H, Rink WJ. 2008. Dating the demise: Neanderthal extinction and the establishment of modern humans in the southern Caucasus. Journal of Human Evolution 55(5):817-33.

Ambrose SH. 1990. Preparation and characterization of bone and tooth collagen for isotopic analysis. Journal of Archaeological Sciences 17(4):431-51.

Anikovich MV, Sinitsyn AA, Hoffecker JF, Holliday VT, Popov VV, Lisitsyn SN, Forman SL, Levkovskaya GM, Pospelova GA, Kuz'mina IE, Burova ND, Goldberg P, Macphail RI, Giaccio B,
Praslov ND. 2007. Early Upper Paleolithic in Eastern Europe and implications for the dispersal of modern humans. Science 315(5809):223-6.

Antoine P, Lautridou JP. 2008. Les formations lossiques en milieux périglaciaires. In: Dewolf Y, Bourrié G, editors. Les formations superficielles. Genèse, typologie, classification, paysages et environnements, ressources et risques. Paris: Ellipses éditions. p 32231.

Arslanov KA, Dolukhanov PM, Gei NA. 2007. Climate, Black Sea levels and human settlements in Caucasus Littoral 50,000-9000 BP. Quaternary International 167-168:121-7.

Bronk Ramsey C. 2009a. Bayesian analysis of radiocarbon dates. Radiocarbon 51(1):337-60. 
Bronk Ramsey C. 2009b. Dealing with outliers and offsets in radiocarbon dating. Radiocarbon 51(3): 1023-45.

Chabai VP. 2001. The Late Middle and Early Upper Paleolithic in Crimea (Ukraine). In: Zilhão J, Aubry $\mathrm{T}$, Carvalho AF, editors. Les premiers hommes modernes de la péninsule ibérique. Actes du colloque de la commission VIII de l'UISPP, Vila nova de Foz Cóa, 22-24 October 1998. Trabalhos de Arqueologia 17: 25-35.

Chabai VP. 2012. The volcanic winter, Buran-Kaya cannibals and the fate of the last eastern European Neanderthals. Arkheologiya (Kyiv) 2012. In Ukrainian.

Chabai VP, Monigal K, Marks AE, editors. 2004a. The Middle Paleolithic and Early Upper Paleolithic of Eastern Crimea. Liège: ERAUL, 104.

Chabai VP, Marks AE, Monigal K. 2004b. Crimea in the context of the eastern European Middle Paleolithic and Early Upper Paleolithic. In: Chabai VP, Monigal $\mathrm{K}$, Marks AE, editors. The Middle Paleolithic and Early Upper Paleolithic of Eastern Crimea. Liège: ERAUL, 104. p 419-60.

Dahl-Jensen D, Johnsen SJ, Hammer CU, Clausen HB, Jouzel J. 1993. Past accumulation rates derived from observed annual layers in the GRIP ice core from Summit, Central Greenland. NATO Advanced Sciences Institutes Series 1:12. Berlin: SpringerVerlag.

Dansgaard W, White JWC, Johnsen SJ. 1989. The abrupt termination of the Younger Dryas climate event. Nature 339(6225):532-3.

Dansgaard W, Johnsen SJ, Clausen HB, Dahl-Jensen D, Gundestrup NS, Hammer CU, Hvidberg CS, Stefensen JP, Sveinbjörnsdóttir AE, Jouzel J, Bond G. 1993. Evidence for general instability of past climate from a $250 \mathrm{kyr}$ ice-core record. Nature 364(6434): $218-20$.

Demidenko YE. 2008. The Early and Mid-Upper Palaeolithic of the North Black Sea region: an overview. Quartär 55:99-114.

DeNiro MJ. 1985. Postmortem preservation and alteration of in vivo bone collagen isotope ratios in relation to palaeodietary reconstruction. Nature 317(6040): 806-9.

Dolukhanov PM, Arslanov KA. 2009. Ecological crises and early human migrations in the Black Sea area. Quaternary International 197:35-42.

Ferrier C. 2002. Les dépôts d'entrée de grotte. In: Miskovsky JC, editor. Géologie de la Préhistoire: méthodes, techniques, applications. Paris: Géopré. $\mathrm{p}$ $189-205$

Fletcher WJ, Sánchez Goñi, MF, Allen JRM, Cheddadi R, Combourieu-Nebout N, Huntley B, Lawson I, Londeix L, Magri D, Margari V, Müller UC, Naughton F, Novenko E, Roucoux K, Tzedakis PC.
2010. Millenial-scale variability during the last glacial in vegetation records from Europe. Quaternary Science Reviews 29(21-22):2839-64.

Gerasimenko N. 2004. Vegetational history of BuranKaya III. In: Chabai VP, Monigal K, Marks AE, editors. The Middle Paleolithic and Early Upper Paleolithic of Eastern Crimea. Liège: ERAUL, 104. p 19-34.

Gerasimenko N. 2007. Environmental changes in the Crimean Mountains during the last Interglacialmiddle pleniglacial as recorded by pollen and lithopedology. Quaternary International 164165:207-20.

Griggo C. 1995. Signification paléoenvironnementale des communautés animales pléistocènes reconnues dans l'abri Suard (Charente) et la grotte de BoisRagot (Vienne): Essai de quantification de variables climatiques [PhD thesis]. Bordeaux: Université Bordeaux I, France.

GRIP Members. 1993. Climate instability during the last interglacial period recorded in the GRIP ice core. Nature 364(6434):203-7.

Grootes PM, Stuiver M, White JWC, Johnsen SJ, Jouzel J. 1993. Comparison of oxygen isotope records from the GISP2 and GRIP Greenland ice cores. Nature 366(6455):552-4.

Hammer CU, Andersen KK, Clausen HB, Dahl-Jensen D, Hvidberg CS, Iversen P. 1997. The Stratigraphic Dating of the GRIP Ice Core. Special Report of the Geophysical Department, Niels Bohr Institute for Astronomy, Physics and Geophysics, University of Copenhagen.

Hedges REM, Housley RA, Pettitt PB, Bronk Ramsey C, Van Klinken GJ. 1996. Radiocarbon dates from the Oxford AMS system: Archaeometry datelist 21. Archaeometry 38(1):181-207.

Higham TFG, Jacobi RM, Bronk Ramsey C. 2006. AMS radiocarbon dating of ancient bone using ultrafiltration. Radiocarbon 48(2):179-95.

Higham TFG, Bronk Ramsey C, Brock F, Baker D, Ditchfield P. 2007. Radiocarbon dates from the Oxford AMS system: Archaeometry datelist 32. Achaeometry 49(S1):S1-S60.

Janevic AA. 1998. Buran-Kaya 3 - Neue Angaben zur Kulturgliederung des Jungpaläolithikums der Krim. Préhistoire Européenne 13:133-48.

Johnsen SJ, Clausen HB, Dansgaard W, Gundestrup NS, Hammer CU, Andersen U, Andersen KK, Hvidberg CS, Dahl-Jensen D, Steffensen JP, Shoji H, Sveinbjörnsdóttir AE, White JWC, Jouzel J, Fisher D. 1997. The $\delta^{18} \mathrm{O}$ record along the Greenland Ice Core Project deep ice core and the problem of possible Eemian climatic instability. Journal of Geophysical Research 102:26,397-410.

Johnsen SJ, Clausen HB, Dansgaard W, Gundestrup NS, Hammer CU, Tauber H. 1995. The Eem stable isotope 
record along the GRIP ice core and its interpretation. Quaternary Research 43(2):117-24.

Jöris O, Street M. 2008. At the end of the ${ }^{14} \mathrm{C}$ time scale - the Middle to Upper Paleolithic record of western Eurasia. Journal of Human Evolution 55(5): 782-802.

Jöris O, Street M, Terberger T, Weninger B. 2011. Radiocarbon dating the Middle to Upper Paleolithic transition: the demise of the last Neanderthals and the first appearance of Anatomically Modern Humans in Europe. In: Condemi S, Weniger GC, editors. Continuity and Discontinuity in the Peopling of Europe: One Hundred Fifty Years of Neanderthal Study. Vertebrate Paleobiology and Paleoanthropology Series. Dordrecht: Springer. p 239-98.

Lanoë F. 2011. Étude archéozoologique de la couche 4 de l'abri de Buran-Kaya III (Ukraine): economie de subsistance au Paléolithique final (Swidérien) en Crimée [Master's thesis]. Paris: Muséum National d'Histoire Naturelle.

Laroulandie V, d'Errico F. 2004. Worked bones from Buran-Kaya III level C and their taphonomic context C. In: Chabai VP, Monigal K, Marks AE, editors. The Middle Paleolithic and Early Upper Paleolithic of Eastern Crimea. Liège: ERAUL, 104. p 83-94.

Lisiecki LE, Raymo ME. 2005. A Pliocene-Pleistocene stack of 57 globally distributed benthic $\delta^{18} \mathrm{O}$ records. Paleoceanography 20: PA1003, doi:10.1029/ 2004PA001071.

Longin R. 1971. New method of collagen extraction for radiocarbon dating. Nature 230(5291):241-2. Markova AK. 2004. Small mammal fauna from BuranKaya III. In: Chabai VP, Monigal K, Marks AE, editors. The Middle Paleolithic and Early Upper Paleolithic of Eastern Crimea. Liège: ERAUL, 104. p 35-48.

Marks AE. 1998. A new Middle to Upper Paleolithic "transitional" assemblage from Buran-Kaya III, Level C, eastern Crimea: a preliminary report. In: Otte M, editor. Préhistoire d'Anatolie, Genèse de deux mondes, I. Liège: ERAUL, 85. p 353-66.

Marks AE, Monigal K. 2000. The Middle to Upper Paleolithic interface at Buran-Kaya-III, Eastern Crimea. In: Orschiedt J, Weniger GC, editors. Neanderthals and Modern Humans - Discussing the Transition:

Central and Eastern Europe from 50,000-30,000 BP. Mettmann: Neanderthal Museum. p 212-26.

Monigal K. 2004. Introduction to the site of Buran-Kaya III. In: Chabai VP, Monigal K, Marks AE, editors. The Middle Paleolithic and Early Upper Paleolithic of Eastern Crimea. Liège: ERAUL, 104. p 3-18.

Naughton F, Sánchez Goñi MF, Kageyama M, Bard E, Duprat J, Cortijo E, Desprat S, Malaizé B, Joly C, Rostek F, Tuon J-L. 2009. Wet and dry climatic trend in north-western Iberia within Heinrich events. Earth and Planetary Science Letters 284(3-4):329-42.

Nelson DE. 1999. A new method for carbon isotopic analysis of protein. Science 251(4993):552-4.

Otte M, Noiret P. 2004. Évolution du Gravettien au Moyen Danube. In: Svoboda J, Sedlácková L, editors. The Gravettian along the Danube. Brno: Institute of Archaeology, The Dolní Vestonice Studies 11. p 832.

Patou-Mathis M. 2004. Archeozoological analysis of large mammal fauna from Buran-Kaya III Layer B. In: Chabai VP, Monigal K, Marks AE, editors. The Middle Paleolithic and Early Upper Paleolithic of Eastern Crimea. Liège: ERAUL, 104. p 95-111.

Pettitt PB. 1998. Middle and early upper Palaeolithic Crimea: the radiocarbon chronology. In: Otte M, editor. Préhistoire d'Anatolie, Genèse de deux mondes. Liège: ERAUL, 85. p 329-38.

Pinhasi R, Higham TFG, Golovanova L, Doronichev VB. 2011. Revised age of late Neanderthal occupation and the end of the Middle Paleolithic in the northern Caucasus. Proceedings of the National Academy of Sciences of the USA 108(21):8611-6.

Prat S, Péan S, Crépin L, Drucker D, Puaud S, Valladas $\mathrm{H}$, Laznickova-Galetova $\mathrm{M}$, van der Plicht J, Yanevich A. 2011. The oldest anatomically modern human from far southeast Europe: direct dating, culture and behaviour. PLos ONE 6(6):e20834.

Reimer PJ, Baillie MGL, Bard E, Bayliss A, Beck JW, Blackwell PG, Bronk Ramsey C, Buck CE, Burr GS, Edwards RL, Friedrich M, Grootes PM, Guilderson TP, Hajdas I, Heaton TJ, Hogg AG, Hughen KA, Kaiser KF, Kromer B, McCormac FG, Manning SW, Reimer RW, Richards DA, Southon JR, Talamo S, Turney CSM, van der Plicht J, Weyhenmeyer CE. 2009. IntCal09 and Marine 09 radiocarbon age calibration curves, $0-50,000$ years cal BP. Radiocarbon 51(4): 1111-50.

Sánchez Goñi MF, Harrison S. 2010. Millennial-scale climate variability and vegetation changes during the last glacial: concepts and terminology. Quaternary Science Reviews 29(21-22):2823-7.

Sánchez Goñi MF, Landais A, Fletcher WJ, Naughton F, Desprat S, Duprat J. 2008. Contrasting impacts of Dansgaard-Oeschger events over a western European latitudinal transect modulated by orbital parameters. Quaternary Science Reviews 27(11-12):1136-51.

Stuiver M, Grootes PM, Braziunas TF. 1995. The GISP2 ${ }^{18} \mathrm{O}$ climate record of the past 16,500 years and the role of the sun, ocean and volcanoes. Quaternary Research 44(3):341-54.

Tisnérat-Laborde N, Valladas H, Kaltnecker E, Arnold M. 2003. AMS radiocarbon dating of bones at LSCE. Radiocarbon 45(3):409-19.

Trinkaus E, Moldovan O, Milota S, Bîlgăr A, Sarcina L, Athreya S, Bailey SE, Rodrigo R, Mircea G, Higham 
TFG, Bronk Ramsey C, van der Plicht J. 2003. An early modern human from the Pestera cu Oase, Romania. Proceedings of the National Academy of Sciences of the USA 100(20):11,231-6. van Klinken GJ. 1999. Bone collagen quality indicators for palaeodietary and radiocarbon measurements. Journal of Archaeological Science 26(6):687-95.

Wood RE, Barroso-Ruíz C, Caparrós M, Jordá Pardo JF, Galván Santos B, Higham TFG. 2013. Radiocarbon dating casts doubt on the late chronology of the Middle to Upper Palaeolithic transition in southern Iberia. Proceedings of the National Academy of Sciences of the USA 110(8):2781-6.

Yanevich A. 2000. Buran-Kaya culture of the Crimea's gravett. Arkheologiya 2:11-20. In Ukrainian.

Yanevich A, Péan S, Crépin L, Lázničková-Galetová M, Prat S, Prysyajnuk V. 2009. Upper Palaeolithic settlements in Buran-Kaya 3 (Crimea, Ukraine): new interdisciplinary researches of the layers 5-2, 6-1 and 6-2. In: Chabai VP, editor. The top issues of the Eastern European prehistoric archaeology. Donetsk: Donbas Archaeological Almanac 20:187-202.

Yanevich AA, Stepanchuk VN, Cohen Yu. 1996. BuranKaya III and Skalistiy Rockshelter: two new dates Late Pleistocene sites in the Crimea. Préhistoire Européenne 9:315-24. 